J. Environ. Sci.

Institute of Environmental Studies and Research - Ain Shams University

\title{
EVALUATION OF DIFFERENT SCREENING METHODS FOR BIOSURFACTANT PRODUCERS ISOLATED FROM EGYPTIAN FRESH WATER SAMPLES CONTAMINATED BY OIL SPILLS USING BACILLUS SUBTILIS AND BACILLUS LICHENIFORMIS
}

\author{
Abd-El Hamid, Noha, E. ${ }^{(1)}$; Arafa, Rawhia, A. ${ }^{(2)}$; Roshdy, M. ${ }^{(2)}$ \\ and Abd-EL Razek, T. M. ${ }^{(1)}$ \\ 1) Institute of Environmental Studies and Research, Ain Shams University \\ 2) Faculty of Science (Girls Branch), Al Azhar University
}

\begin{abstract}
In all countries, oil exploration and use threatens the health of the environment and living creatures including humans. An oil spill is the release of petroleum hydrocarbon into the environment. One of the most applicable and safe method is the bioremediation treatment, using microorganisms. This work aims at treating oil spills in fresh water and to compile information on types and properties of biosurfactant. It also describes factors affecting these biosufactants production. Different screening methods e.g. oil spreading assay, Emulsification index (E24), Drop collapse assay, Blood agar test, Hemolysis, MaCconkey agar test were tested. Two isolates gave highly Emulsification tests named O3, O11, which were identified as Bacillus subtilis and Bacillus licheniformis respectively, were isolated from petroleum hydrocarbon contaminated water. Optimization of two isolates were done and highest biosurfactant activity at temperature ranges from $10 \mathrm{oC}$ to $50 \mathrm{oC}$ and $\mathrm{pH}$ ranges from 3 to 10 and salinity ranges from $0 \%$ to $30 \%$. Also, the biosurfactant was characterized by Fourier transform infrared spectroscopy (FTIR) and surface tension measurement. FTIR showed the production of biosurfactant from Bacillus subtilis similar to surfactin, while the biosurfactant from Bacillus licheniformis similar to lichenysins. The use of microbial biosurfactants significantly decreases the hydrophobicity and increases the rate of hydrocarbon biodegradation. Biosurfactants obtain
\end{abstract}


demonstrated good surface tension reduction capacity by Bacillus subtilis and Bacillus licheniformis up to 30 and $36 \mathrm{Nm} / \mathrm{m}$ and have emulsifying activity $71 \%$ and $65 \%$ respectively.

Keywords: Bioremediation-Biosurfactant-Oil spill-Surface tension-FTIR.

\section{INTRODUCTION}

Crude oil is liquid petroleum containing thousands of hydrocarbon components. Each component has a unique chemical behavior that makes it either easily biodegradable, quite difficult to digest or not degradable at all .Petroleum hydrocarbon molecules can be grouped into four broad categories: saturates (branched, unbranched and cyclic alkanes), aromatics - ringed hydrocarbon molecules such as monocyclic aromatic hydrocarbons (MAHs) and polycyclic aromatic hydrocarbons(PAHs), resins and asphalthenes. In the structural arrangement of the four main hydrocarbon components of crude oil, saturates make up the outermost layer of the oil whilst asphalthenes constitute the innermost portion of the oil due to their greater molar masses(Macaulay and Rees, 2014).

The problem is that petroleum is a highly complex mixture of thousand of compounds, many of which cause toxicity to living organisms. Petroleum causes a variety of impacts on animals, including impaired reproduction, decreased resistance to disease, anemia, cancer, neurological damage, and birth defects in offspring. Petroleum impairs photosynthesis, and many physiological processes of Phytoplankton and plants cumulating in inhibition of growth or death. Birds and mammals become coated with oil and their feathers and fur lost property of insulation. Feathers and fur provide insulation by trapping a layer of air between the skin and the external 
J. Environ. Sci.

Institute of Environmental Studies and Research - Ain Shams University

environment, and thus protects animals from cold (Ramesh and Somashaker, 2014).

To clean-up oil and grease, so many methods were used before which are economically very costly and will affect the environment (Ramesh and Somashaker, 2014). A primary way to contain and collect oil is by the use of containment boom and barrier; the oil can then be recovered by a skimmer (Walther and Henry, 2014). Dispersants were also used as well as Absorbents, while Burning was used successfully on beaches and on isolated slicks (Al-Majed et al., 2012), then came Bioremediation (Wang et al., 2011).

Bioremediation is a technology based on the activation of microbial degradation of pollutants in contaminated sites by optimizing environmental factors (Skladany and Metting, 1993).

Biosurfactants have gained increased attention because of their biodegradability, low toxicity, ability to be produced from cheap raw materials and effectiveness at extreme conditions of temperature, $\mathrm{pH}$ and salinity (Badour et al., 2002).

Screening and selection of bio-surfactant candidate bacterial strains from diverse habitats is an interesting area of research that enhances both our collective knowledge and cache of microorganisms that can serve industrially significant processes. A number of approaches are employed in the isolation and screening of bacterial isolates that are capable of degrading petroleum hydrocarbons via bio surfactant production (Hassan et al., 2018).

This work aims at treating oil spills in fresh water and to compile information on types and properties of biosurfactant, microbial screening methods as well as biosynthesis, extraction of biosurfactant. It also describes 
factors affecting these biosufactants production. Two bacterial strains from eight, Bacillus subtilis and Bacillus lichenformis isolated from petroleum hydrocarbon contaminated water.

\section{MATERIALS AND METHODS}

Sampling: For the isolation of biosurfactant producing bacteria, two oil polluted samples were collected one from Ismailia canal near mustard and the other one a little bit far by few metres. Eight microorganisms were obtained from the polluted samples with oil spills.

\section{Materials:}

\section{$\underline{\text { LB (Luria-Bertani) MEDIUM }}$}

Tryptone $10.0 \mathrm{~g}$

Yeast extract $5.0 \mathrm{~g}$

$\mathrm{NaCl} 10.0 \mathrm{~g}$ in case of sea water

Agar $20.0 \mathrm{~g}$

Distilled water $1000.0 \mathrm{ml}$

A $\mathrm{pH}$ to 7.0.with modification yeast extract $10 \mathrm{~g}$ in both cases and $\mathrm{NaCl}$ $5 \mathrm{~g}$ in case of fresh water (Biniarz and Lukaszewicz., 2017) supplemented with glucose $5 \mathrm{mg}$ as a sole Carbon source.

\section{Methods:}

Isolation of Crude Oil Bacteria Producing Biosurfactant: The sterilized media was spread on sterile petri-plates under aseptic conditions, after that the samples were added by direct method. Only $1 \mathrm{ml}$ from each water polluted with oil. The plates were incubated at $30^{\circ} \mathrm{C}$ until the microbial colonies developed (April et al., 2000). 
Purification of the Isolates: The purification procedure of these crude oil utilizing microbial isolates were carried out by agar streak method according to (Bertani, 2004).

Morphology of Isolate and Gram Staining: Morphology and Gram staining were done according to (Ismail, 2008).

Growth on MacConkey Agar Medium: All isolates were streaked on MacConky agar medium which is a selective and differential medium designed to isolate and differentiate enterics based on their ability to ferment lactose. Bile salts and crystal violet inhibit the growth of Gram positive organisms. Lactose provides a source of fermentable carbohydrate, allowing for differentiation. Incubation at $30^{\circ} \mathrm{C}$ for $24 \mathrm{hr}$; the growth of the tested isolates was investigated after that incubation time according to (Athar $e t$ al., 2014).

Oil Spreading Assay: This method was employed to check the efficacy of the culture medium in displacing the oil layers, $1 \mathrm{ml}$ of crude oil was added to the surface of $30 \mathrm{ml}$ of distilled water in a Petri-dish to form a thin oil layer, $20 \mu \mathrm{l}$ of culture supernatant was gently dropped on the centre of the oil layer, after one minute if the sample was +ve (containing biosurfactant), the oil is displaced and a clearing zone was measured (Morikawa et al., 2000).

Drop Collapse Assay: It is a rapid and crude method to assess thesurfactant activity In brief, about $10 \mu \mathrm{l}$ of cell free broth was added inthe center of an oil drop (20 $\mu 1$ of any oil) taken in a clean glass slide. The collapse of oil drop hasbeen visualized and the less time taken indicates the higher activity of surfactant (Jain et al., 1991). 
Emulsification Index: The emulsion index was calculated after 24 hours; hence it is also called E24. Emulsion index was measured in percentage by diving the height of the emulsion to the total height of the mixture. The procedure is described as follows:

- $6 \mathrm{ml}$ Distilled water+2 $\mathrm{ml}$ immersion oil

- The sample was vortexed for $10 \mathrm{~min}$

- The mixture was allowed to settle down

- $2 \mathrm{ml}$ crude biosurfactant sample was added

- Again the sample was vortexed for $10 \mathrm{~min}$ and settled for $24 \mathrm{hrs}$.

Emulsion was observed (Rikalovic et al., 2012 and Mukherjee et al., 2006). Modification happens ( $1 \mathrm{ml}$ broth $+5 \mathrm{ml}$ water + a drop of crude oil). The E24 index is calculated by using the following equation (Sidkey et al., 2016)

$E 24=($ Height of emulsion formed x 100)/(Total height of the solution)

Hemolytic activity: A pure culture of each bacterial isolate was streaked on the freshly prepared blood agar and incubated at 37 o $\mathrm{C}$ for $48-72$ Hrs. Results were recorded based on the type of clear zone observed (Plaza et al., 2006 and Youssef et. al., 2004).

Oil Spreading Method: Oil spreading technique was carried out. Briefly, 5 $\mathrm{mL}$ of distilled water was added to the Petri plate followed by addition of 1 $\mathrm{mL}$ of crude oil to the surface of the water. Then, $2 \mathrm{~mL}$ of cell-free culture broth was dropped on the crude oil surface. The diameter of the clear zone on the oil surface was measured and compared to $10 \mathrm{~mL}$ of distilled water as a negative control (Sharma et al., 2014). 
J. Environ. Sci.

Institute of Environmental Studies and Research - Ain Shams University

Fourier Transform Infrared Spectroscopy: The biosurfactant extract recovered from the supernatant of the bacterial isolate was characterized by Fourier transform infrared spectroscopy (FTIR). The FTIR spectra using Perkin Elmer - spectrum one, controlled by Spectrum Software Version 3.2. In the range of 650-4000 cm-1 (Egyptian Petroleum Research Institute) through HATR technique (Chandankere et al., 2013).

Surface Tension: The surface tension of the culture supernatants was measured using Theta Lite -surface tensiometer - Biolin Scientific , according to ASTM D1331 - 14 " Standard Test Methods for Surface and Interfacial Tension of Solutions of Paints, Solvents, Solutions of SurfaceActive Agents, and Related Materials".

Biosurfactant Stability Tests: Stability studies (optimization) were carried as described by (Obayori et al., 2009). The stability of the biosurfactants against $\mathrm{pH}$, temperature, salinity was determined as following with some modifications:

Optimization of the Isolate According to Temperature: Optimization is made by broth containing LB (Luria-Bertani) Broth. Adjust temperature as follows to $10 \mathrm{oC}, 20 \mathrm{oC}, 30 \mathrm{oC}, 40 \mathrm{oC}, 50 \mathrm{oC}$. The broth is sterilized and put in different incubators for 7 days then 10 days.

Optimization of the Isolate According to pH: Optimization is made by broth containing LB (Luria-Bertani) Broth. Adjust $\mathrm{pH}$ as follows to 3, 4, 5, 6, 7, 8, 9, and 10. The broth is sterilized and put in incubators according to optimum temperature of each microorganism for 7 days then 10 days.

Optimization of the Isolate According to Salinity: Optimization is made by broth containing LB (Luria-Bertani) Broth. Adjust salinity as follows to $0 \%$, 
$3 \%, 5 \%, 10 \%, 15 \%, 20 \%, 25 \% .30 \%$. The broth is sterilized and put in incubators according to optimum temperature and $\mathrm{pH}$ of each microorganism for 7 days.

Bacteria identification was Done by Biolog (Bochner, 1989): Two strains of the isolated microorganisms were identified by Biolog GEN III MicroPlateTM.

\section{RESULTS AND DISCUSSION}

Biosurfactants have better surface activity, lower toxicity, they can bind heavy metals, have higher biodegradability, selectivity and biological activity, they are produced from renewable resources, can be produced through fermentation and can be reused by regeneration. The other advantages of microbial surfactants are eco-friendly, high foaming ability and efficiency at extreme temperatures, $\mathrm{pH}$ and salt concentrations (Sidkey et al., 2016) .From two contaminant fresh water samples by oil spill, eight isolates were selected for studying cell morphology as in table(1).

Table (1): Morphology of isolates, Forms of isolates, Gram staining, MaCconkey test

\begin{tabular}{|c|c|c|c|}
\hline Fresh Isolates & Form & GRAM Staining & MaCconkey Test \\
\hline 6 & Creamy & POSITIVE & POSITIVE \\
\hline 7 & Creamy & NEGATIVE & NEGATIVE \\
\hline 8 & Creamy & NEGATIVE & NEGATIVE \\
\hline 9 & Transparent & POSITIVE & POSITIVE \\
\hline O1 & Creamy & POSITIVE & POSITIVE \\
\hline O11 & Yellowish & POSITIVE & POSITIVE \\
\hline O2 & Creamy & POSITIVE & POSITIVE \\
\hline O3 & Creamy & POSITIVE & POSITIVE \\
\hline
\end{tabular}


Several tests were done as oil displacement test, emulsifying activity, hemolytic activity, gram staining, oil collapse test, Optimization of the microorganisms according to $\mathrm{pH}$, temperature, salinity to know the best conditions for these microorganisms to get the best yield of their biosurfactants for the eight isolated strains as shown in table 1, 2 .

Table (2): Screening tests to the isolates Blood agar test, oil spreading assay, oil collapse assay, E24 test

\begin{tabular}{|c|c|c|c|c|c|}
\hline $\begin{array}{c}\text { Fresh } \\
\text { Isolates }\end{array}$ & $\begin{array}{c}\text { Blood } \\
\text { Agar Test }\end{array}$ & $\begin{array}{c}\text { Lactose } \\
\text { Fermentation }\end{array}$ & $\begin{array}{c}\text { Oil } \\
\text { Spreading } \\
\text { Assay } \\
\text { Diameter }\end{array}$ & $\begin{array}{c}\text { Oil } \\
\text { Collapse } \\
\text { Assay }\end{array}$ & E24\% \\
\hline \hline 6 & Beta & None & $2 \mathrm{~cm}$ & Positive & Negative \\
\hline 7 & Gamma & $\begin{array}{c}\text { Lactose } \\
\text { Fermentor }\end{array}$ & $7 \mathrm{~cm}$ & Positive & Negative \\
\hline 8 & Beta & $\begin{array}{c}\text { Lactose } \\
\text { Fermentor }\end{array}$ & $2 \mathrm{~cm}$ & Positive & Negative \\
\hline 9 & Beta & None & $7 \mathrm{~cm}$ & Positive & Negative \\
\hline O1 & Beta & None & $6 \mathrm{~cm}$ & Positive & $57 \%$ \\
\hline O11 & Gamma & None & $6 \mathrm{~cm}$ & Positive & $65 \%$ \\
\hline O2 & Beta & None & $5 \mathrm{~cm}$ & Positive & Negative \\
\hline O3 & Beta & None & $6.5 \mathrm{~cm}$ & Positive & $71 \%$ \\
\hline
\end{tabular}

Then the most potent microorganisms O3, O11 were identified by Biolog as Bacillus subtilis, Bacillus licheniformis respectively.

Hemolytic activity: The culture supernatants of Bacillus subtilis and Bacillus lichenformis strains exhibited hemolytic activity, the first beta hemolytic while the second is gamma. They produced B-hemolysis pattern, i.e. complete lysis of red blood cells. These hemolytic zones were related to the ability of these bacterial strains to produce biosurfactants which was in agreement with Plaza et al.2006; Youssef et al.2004 who reported that the 
existence of a relationship between the hemolytic activity and biosurfactant production. They suggested the use of blood agar test, hemolysis as a primary method for screening as in Table(3).

Drop Collapse Assay: Results of wetting activity investigated by using the drop collapse test revealed that Bacillus subtilis and Bacillus licheniformis strains were capable of producing biosurfactant as in Table(3). The drop collapsing assay relies on the capacity of surfactants to destabilize the liquid droplets on an oily surface which is in agreement with Jain et al., 1991.

Growth on MacConkey Agar Medium: The strains B. subtilis and B. licheniforms showed no growth on MacConkey and showed no lactose fermentation as in Table (3), Such trend was in agreement with Athar et al., 2014.

Oil Spreading Assay: The oil displacement method measures the surface activity of a surfactant solution tested against crude oil; the larger the diameter of displaced circle the higher surface activity of the surfactant . Biosurfactant produced by Bacillus subtilis culture showed higher surface activity, the diameter of displaced circle was $6.5 \mathrm{~cm}$ while in case of Bacillus licheniformis strains were $6 \mathrm{~cm}$ as in Table(3). This was in agreement with Kiran et al., 2010.

Emulsification Index (E24 \%): E24 of the eight isolates ranges from 57\% to $71 \%$. The cell-free culture broth of both strains was successfully emulsified crude oil. The highest E24 value recorded by Bacillus subtilis biosurfactant was $71 \%$ compared to $65 \%$ for Bacillus licheniformis ,so it could be stated that the bacterial strains under study can produce biosurfactants and 
J. Environ. Sci.

Institute of Environmental Studies and Research - Ain Shams University

bioemulsifier as in Table(3), This is in agreement with study of (Sidkey et al., 2016).

Table (3): Comparison between B. subtilis and B. licheniformis in growth criteria and activity

\begin{tabular}{|c|c|c|}
\hline Test & Bacillus subtilis & Bacillus lichenformis \\
\hline Gram stain & gram +ve & gram +ve \\
\hline Blood agar (hemolysis) & Beta & Gamma \\
\hline Growth on MaCconky & Negative & Negative \\
\hline Lactose fermentation & None & None \\
\hline Oil collapse & Positive & Positive \\
\hline Oil spreading assay & $6.5 \mathrm{~cm}$ & $6 \mathrm{~cm}$ \\
\hline Optimum temperature for growth & 40 & 20 \\
\hline Optimum pH for growth & 6 & 7 \\
\hline Optimum Salinity for growth & $5 \mathrm{~g} / 1$ & $0 \mathrm{~g} / 1$ \\
\hline Emulsification & $71 \%$ & $65 \%$ \\
\hline
\end{tabular}

In comparison between two isolates Bacillus subtilis and Bacillus licheniformis, was found in Blood hemolysis and temperature range and Emulsification index.

Optimization of the Isolate According to $\mathrm{pH}$, Temperature, Salinity: Optimization of two isolates Bacillus subtilis and Bacillus licheniformis were done.The results of optimization agreed with Desai and Banat (1997) who elucidated that, environmental factors and growth conditions such as $\mathrm{pH}$, temperature affect biosurfactant production through their effects on cellular growth or activity.

Several studies have aimed to optimize the biosurfactant production process by changing the variables that influence the type and amount of biosurfactant produced by a microorganism. Important variables are carbon and nitrogen sources (Santos et al., 2002), also the use of glucose as a sole 
carbon source enhances the production of high yield of Biosurfactants (Fooladi et al .2013). Potential nutrient limitations and other physical and chemical parameters such as oxygen (Kronemberger et al., 2008), temperature and $\mathrm{pH}$ (Mukherjee et al., 2006) were considered.

Fig. 1 shows that optimum temperature for Bacillus subtilis is $40{ }^{\circ} \mathrm{C}$ and for Bacillus licheniformis is $20{ }^{\circ} \mathrm{C}$, also shows that optimum temperature for Bacillus subtilis is $30{ }^{\circ} \mathrm{C}, 40{ }^{\circ} \mathrm{C}, 50{ }^{\circ} \mathrm{C}$ and Bacillus licheniformis is $20{ }^{\circ} \mathrm{C}$ after incubation for 10 days.

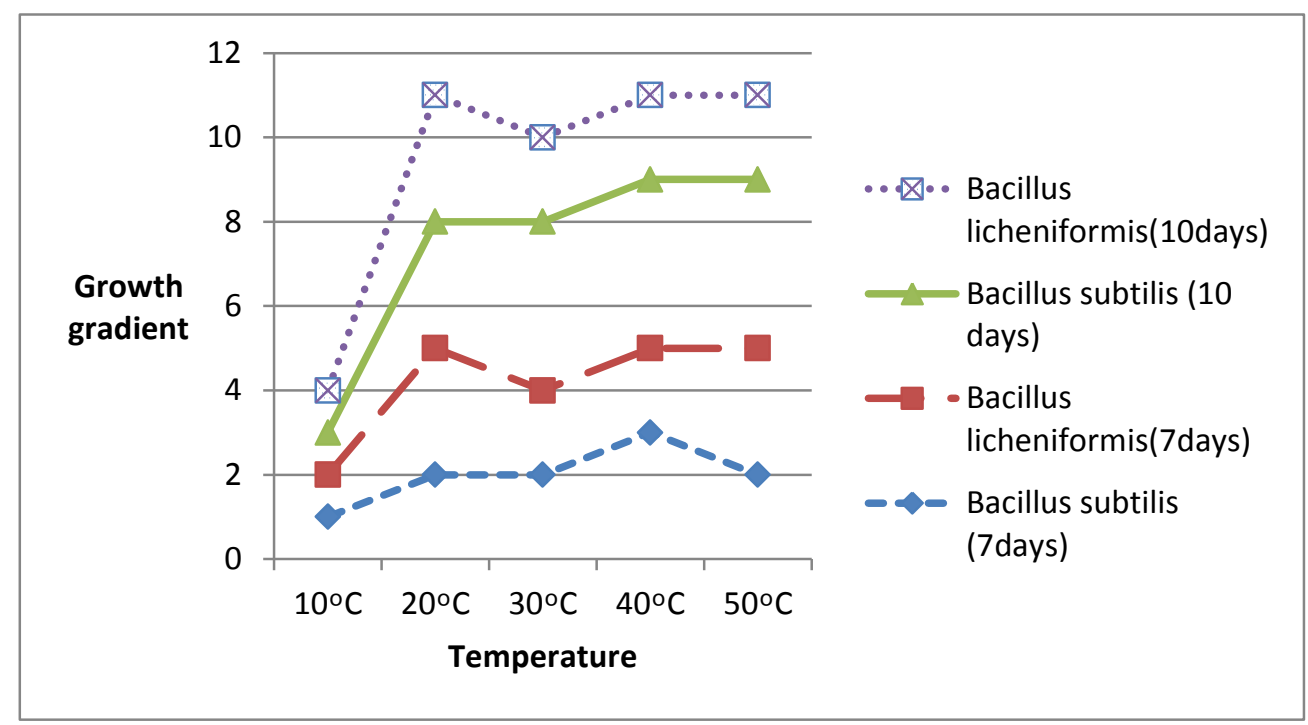

Fig (1): Growth Gradient by temperature after incubation period of $7 \& 10$ days

Fig (2): shows that optimum pH for Bacillus subtilis is 6 and for Bacillus licheniformis is 7 , also shows that optimum $\mathrm{pH}$ for Bacillus subtilis and Bacillus licheniformis is 7 after incubation for 10 days. 
J. Environ. Sci.

Institute of Environmental Studies and Research - Ain Shams University

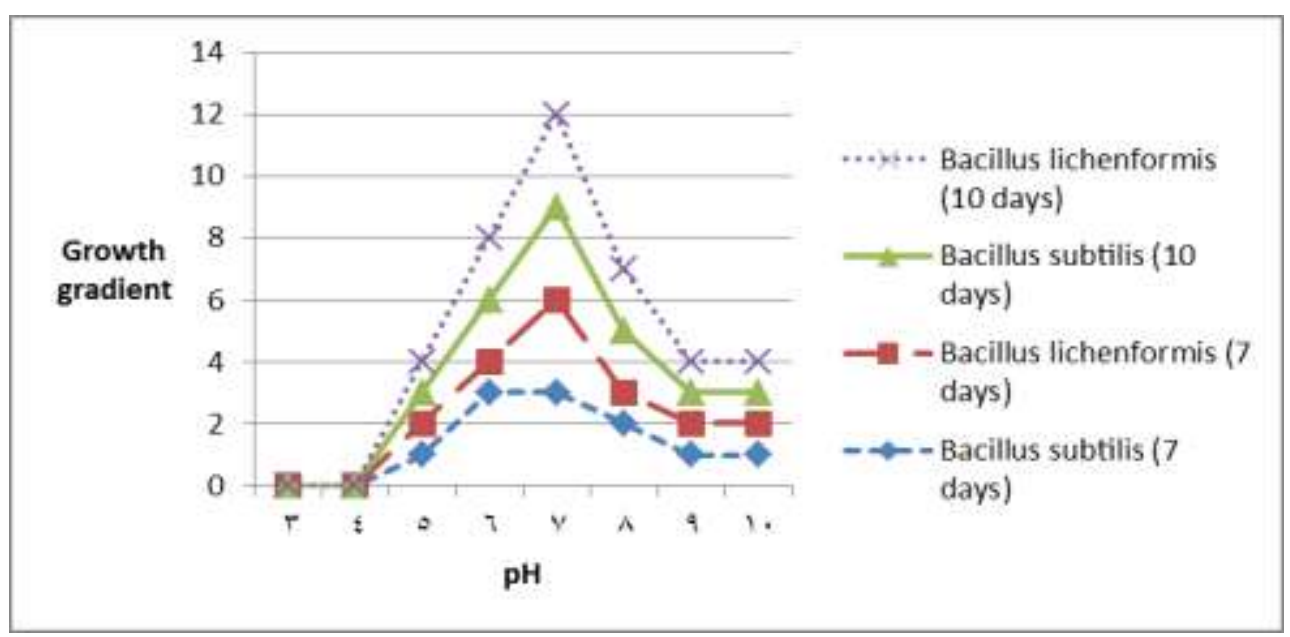

Fig. (2): Growth gradient according to $\mathrm{pH}$ value after incubation period of 7 $\& 10$ days.

Fig. 3 shows the optimum salinity for Bacillus subtilis is $5 \mathrm{~g} /$ land for Bacillus licheniformis is 0 .

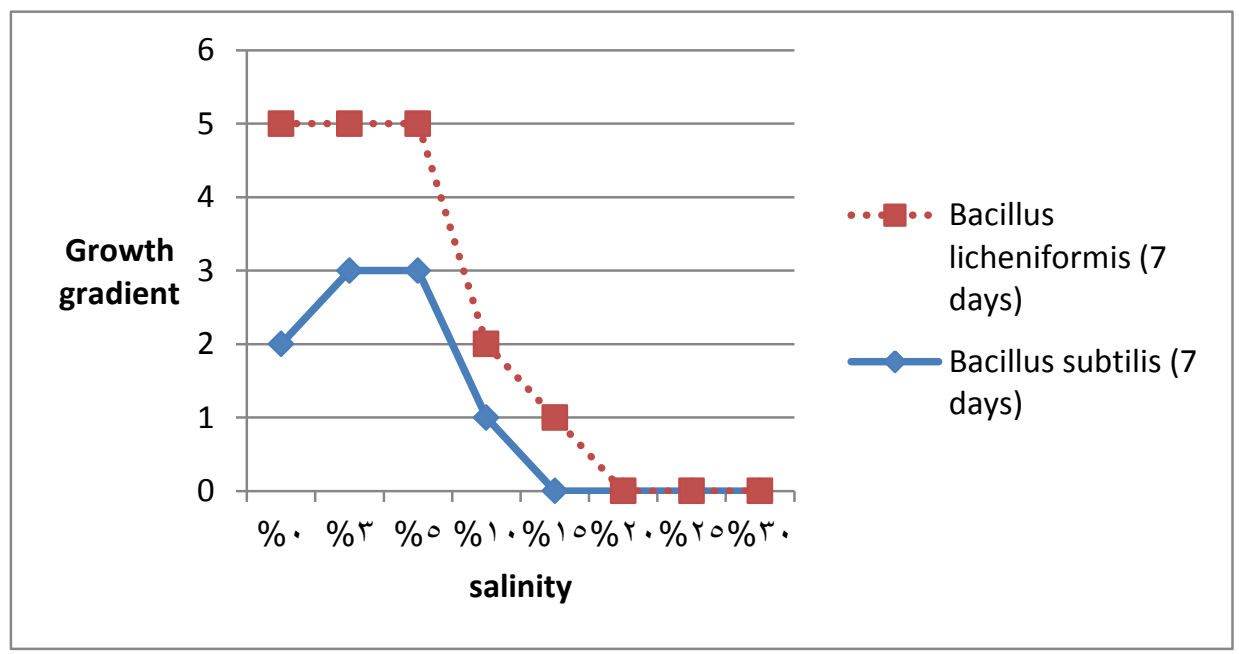

Fig. (3): Growth gradient according to salinity concentration $\mathrm{g} / \mathrm{l}$ after incubation period of 7 days 
Surface Tension Measurement:

\begin{tabular}{|c|c|}
\hline Name of Isolate & Results of Surface Tension by Nm/m \\
\hline Control & 49 \\
\hline Bacillus subtilis & 30 \\
\hline Bacillus licheniformis & 36 \\
\hline
\end{tabular}

Based on surface tension measurement, the cell-free supernatants of strains showed a remarkable reduction in surface tension, Bacillus subtilis biosurfactant was observed to have higher surface tension reduction capacity up to $(30 \mathrm{mN} / \mathrm{m})$ than Bacillus lichenformis that was up to $(36 \mathrm{mN} / \mathrm{m})$. While the distilled water and control gave 72 and $49 \mathrm{mN} / \mathrm{m}$, respectively compared with study of (Jenny et al., 1991).

\section{FTIR Curves:}

FTIR curves to the two strains are done as the following: The first FTIR curve(1) for Bacillus lichenformis containing amide-alcohol (-OH)-alcoholamide-ketones $(-\mathrm{C}=\mathrm{O})$-nitro-aldehyde $(-\mathrm{NH})$-terminal di substituted alkenecis di substituted alkene groups (similar to lichenysins biosurfactant) compared by lipopeptide in study of (Suthar and Nerurkar, 2016).The second FTIR curve(2) for Bacillus subtilis containing amide -amide - alcohol ketones - asymmetric nitro-symmetric nitro-mono substituted alkene-terminal di substituted alkene groups, similar to surfactin biosurfactant compared to lipopeptide in study of (Joshi et al., 2008). 
J. Environ. Sci.

Institute of Environmental Studies and Research - Ain Shams University

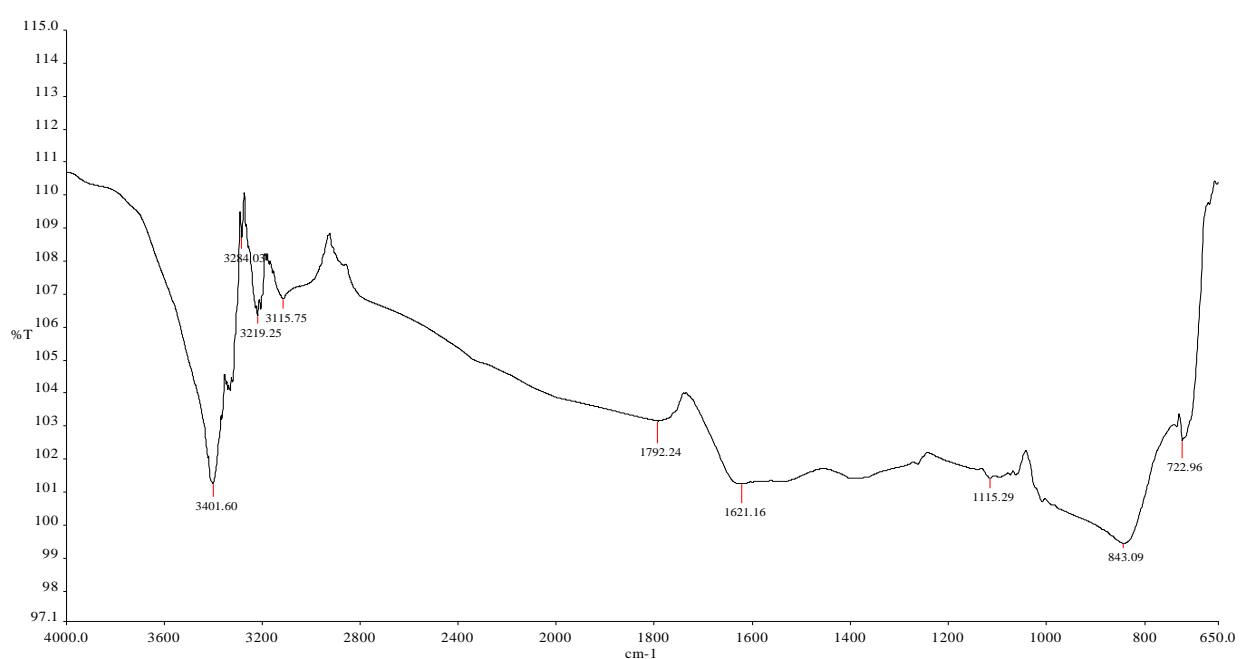

FTIR curve (1): for Bacillus licheniformis biosurfactant similar to lichenysins

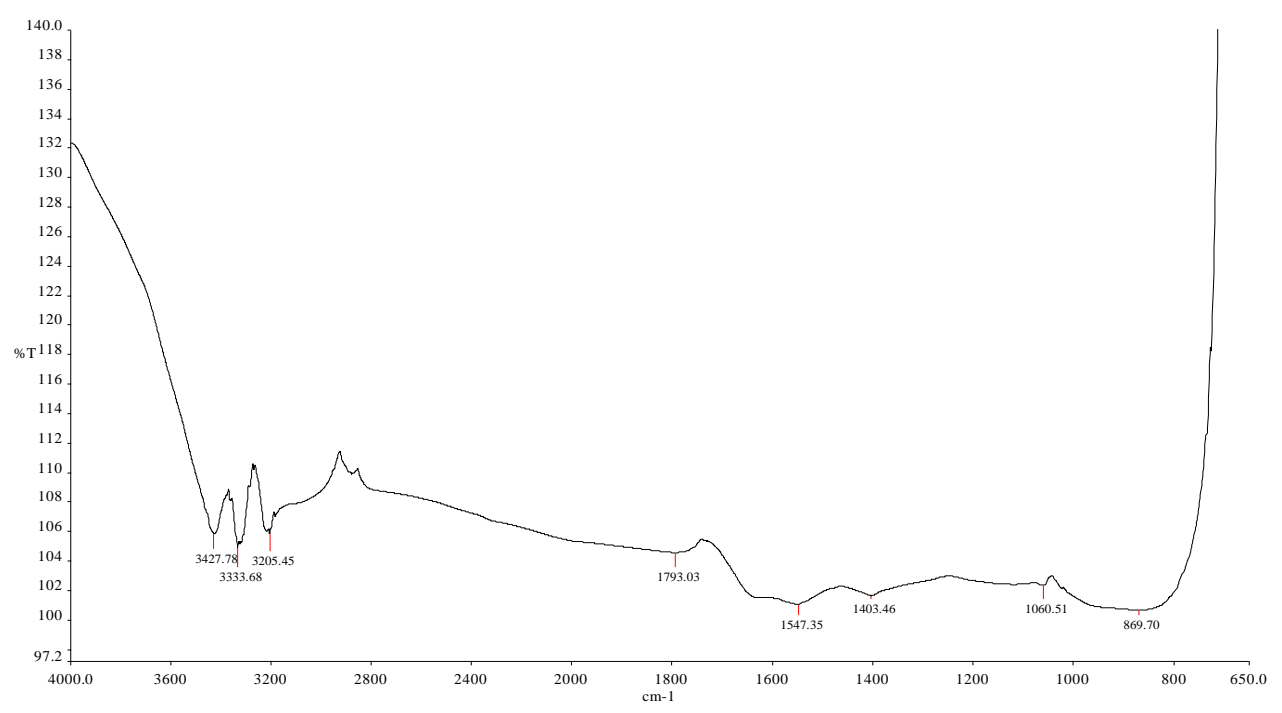

FTIR curve (2): for Bacillus subtilis biosurfactant similar to surfactin 


\section{CONCLUSION}

The Bacillus subtilis and Bacillus lichenformis strains, isolated from fresh water contaminated with oil spill, are capable of producing high yield of biosurfactants and bioemulsfiers. The preliminary chemical characterization revealed that they belong to the lipopeptides. Bacillus subtilis strain are capable of producing a biosurfactant similar to surfactin and Bacillus lichenformis strain are capable of producing a biosurfactant similar to lichenysins. In terms of the surface activities, the crude biosurfactants showed comparable physicochemical properties. .Indeed, they are capable of forming stable emulsions with a variety of hydrophobic compounds, and their activities are not affected by exposure to exaggerated environmental conditions. The features of these biosurfactants and bioemulsfiers make them an interesting biotechnological product for many environmental and industrial applications such as bioremediation processes and Microbial enhanced oil recovery.

\section{REFERENCES}

Al-Majed, A.A.; Adebayo, A.R., and Hossain, M.E., (2012): A Novel sustainable oil spill control Technology. J. Environmental Engineering and Management: 1-21.

April, T.M.; Foght, J.M., and Currah, R.S., (2000): Hydrocarbon degrading filamentous fungi isolated from flare pit soils in northern and western canada.J. Microbiol.46:38-49.

Athar, M.A.; Akbar, A.; Khan, Y.H.; Ali I.; Mehmood, U.;Sabri, A. N., and Hasnain, s., (2014): Characterization of Hydrocarbon Degrading Bacteria Isolated from Hydrocarbon Contaminated Soil. J. Pure and Applied Microbiology (8). 
Badour, A. A.; Drees, K. p. and Maier, R. M., (2002): Biosurfactants:types, screening methods and application. Encyclopedia of Environmental Microbiology, vol.2.wiley, New York,750-769.

Bertani G., (2004): Lysogeny at mid-twentieth century: P1, P2, and other experimental systems. J. Bacteriol. 186:595-600.

Biniarz, p., and Łukaszewicz, M. (2017): Direct quantification of lipopeptide biosurfactants in biologicalsamples via HPLC and UPLC-MS requires sample modificationwith an organic solvent. J. Appl Microbiol Biotechnol 101:4747-4759.

Bochner, BR 1989. Sleuthing out Bacterial Identities. Nature 339:157-158.

Chandankere, R.; Jun, Y.; Choi, M.M.F.; Masakorala, K., and Chan, Y. (2013): An efficient biosurfactant-producing and crude-oil emulsifying bacterium Bacillus methylotrophicus USTB a isolated from petroleum reservoir. Biochem. Eng. J. 74: 46 -53.

Desai, J.D., and Banat, I.M.(1997): Microbial production of surfactants and their commercial Reviews, 61: 47- 64.

Fooladi, T.; Abd Hamid, A.B.; Youssef, W.M.W.; Moazami, N., and Shafiee, Z., (2013): Production of Biosurfactant by Indigenous Isolated Bacteria in Fermentation system.https://doi.org/10.1063/1.4858654

Hassan, k.A.; Sani Y., and Ajoke, O.Y., (2018); Preliminary Screening of Bio-surfactant ProducingBacteria Isolated from an Oil Contaminated Soil. Asian Journal of Biochemistry, Genetics and MolecularBiology1(1): 1-9

Ismail, A.B., (2008): Isolation, Characterization andIdentification of microorganisms from soil contaminated with pesticide, p.19.

Jain, D.K; Thompson D.L.C; Lee H., and Trevors J.T., (1991). A drop collapsing test for screeningsurfactant producing microorganisms.Journal of Microbiological Methods.,13(4):271279. 
Jenny, K.; Kappli, O., and Fiechter, A., (1991):.Biosurfactants from Bacillus licheniformis structural anaylsis and characterization.J.Applied Microbiol Technol (36):5-13.

Joshi S.; Bharucha C., and Desai A.J., (2008): Production of biosurfactant and antifungal compound by fermented food isolate Bacillus subtilis 20B. Bioresour Technol, 99: 4603-4608.

Kiran, G.S.; Thomas T.A; Selvin, J.; Sabarathnam, B., and Liptonm, AP., (2010): Optimization and characterization of a new lipopeptide biosurfactant produced by marine Brevibacterium aureum MSA13 in solid state culture. Bioresour. Technol, 101: 23892396.

Kronemberger, F.D.A.; Santa Anna, L.M.M.; Fernandes, A.C.L.B.; Menezes, R.R.D.; Borges, C.P., and Freire, D.M.G., (2008): Oxygencontrolled biosurfactant production in a bench scale bioreactor.J.Appl Biochem Biotechnol. 147 (Issue 1-3): 33-45.

Macaulay, B.M., and Rees D., (2014):.Bioremediation of oil spills: A review ofchallenges for research advancement, J. Annals of Environmental Science. (8): 9-37

Morikawa, M.; Hirata Y., and Imanaka T. A., (2000): study on the structurefunction relationship of lipopeptides biosurfactants. J. of Biochemical et Biophysical Acta.1488:211-218.

Mukherjee, S.; Das, P., and Sen, R., (2006): Towards commercial production of microbial surfactants. Trends Biotechnol 24: 509-515.

Obayori, O.S.; Ilori, M.O.; Adebussoye, S.M.; Oyetibo, G.O.; Omoayo, A.E., and Amund, O.O., (2009): Degradation of hydrocarbons and biosurfactant production by pseudomonas sp. Strain LPI . J. Micrbiol. Biotechnol.,25: 1615-1623.

Plaza, G.A.; Zjawiony, I., and Banat, I.M., (2006): Use of different methods for detection of thermophilic biosurfactant-producing bacteria from hydrocarbon- contaminated and bioremediated soils, J. Petrol. Sci. Eng. 50:71-77. 
Ramesh, M.A., and Somashekar, P., (2014): Bioremediation of oil spill an invasion by Bacteria to a safe Environment. Indian Journal of Applied Research.4 :(9):28-30.

Rikalovic, M.G.; Gojgic-Cvijovic, G.; Vrvic, M.M, and Karadžic I , (2012): Production and characterization of rhamnolipids from Pseudomonas aeruginosa san-ai. J. SerbChem Soc 77: 27-42.

Santos, A. S.; Sampaio, A.P.W.; Vasquez, G.S.; Santa Anna, L.M.; Pereira, Jr.N. and Freire, D.M.G., (2002): Evaluation of different carbon and nitrogen sources in production of rhamnolipids by a strain of Pseudomonas aeruginosa.J Applied Biochemistry and Biotechnology. 98-100, (1-9):1025-1035.

Sharma, A.; Soni, J.; Kaur, G., and Kaur, J., (2014): A Study on biosurfactant production in Lactobacillus and Bacillus sp, Int. J. Curr. Microbiol. Appl. Sci. 3 (11): 723-733.

Sidkey, N.; Mohamed, H. F., and Elkhouly, H., (2016): Evaluation of Different Screening Methods for Biosurfactant Producers Isolated from Contaminated Egyptian Samples Grown on Industrial Olive Oil Processing Waste. J British Microbiology Research 17(4):119.

Skladany, G.J., and Metting, F.B., (1993): Bioremediation of contaminated soil.In: Soil Microbial Ecology.Metting F. B. Tr (Ed) Marcel Dekker, New York, pp.483-513.

Suthar, H., and Nerurkar A., (2016): Characterization of Biosurfactant Produced by Bacillus licheniformis TT42 Having Potential for Enhanced Oil Recovery.J. Appl. Biochem. Biotechnol DOI 10.1007/s12010-016-2096-6.

Walther, and Henry, R.III, (2014): Clean up Techniques used for coastal oil spills: An analysis for oil Spills Occurring in Santa Barbara, California, Prince William Sound, Alaska, the Sea of Japan, and the gulf coast Master's Projects: 104. 
Wang, Q.; Zhang, S.; Li, Y., and Klassen, W., (2011):.Potential Approaches to Improving Biodegradation of Hydrocarbons for Bioremediation of Crude Oil Pollution. Journal of Environmental Protection.(2):47-55.

Youssef, N.H.; Duncan, K.E.; Nagle, K.N.; Savage, K.N.; Knapp, R.M., and McInerney, M.J., (2004): Comparison of methods to detect biosurfactant production by diverse microorganisms, J. Microbiol. Methods 56: 339-347.

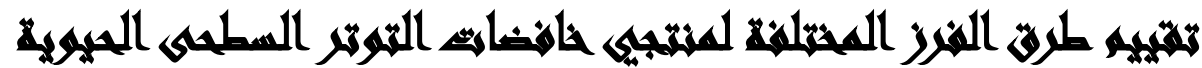

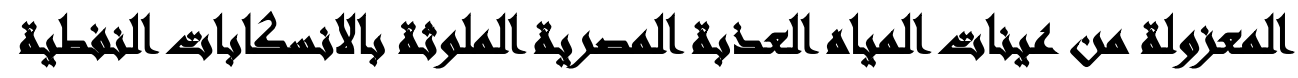

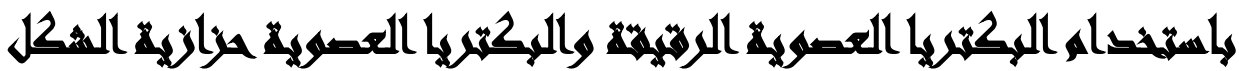

\section{[r]}

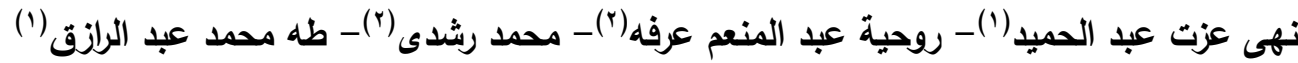

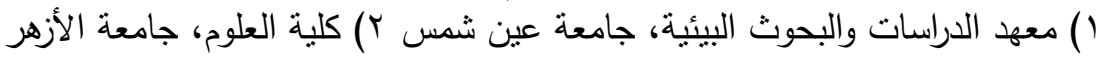

\section{variand}

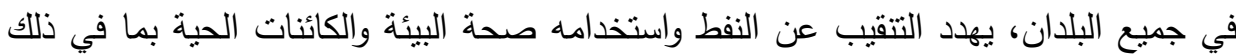
البشر • ويُعرف الانسكاب النفطي على أنه تسرب للهيدروكربونات النفطية إلى البيئة. وتُعد المعالجة

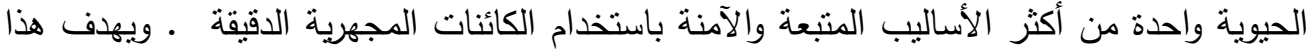

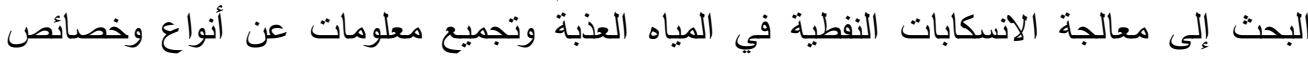

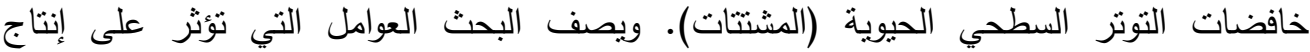

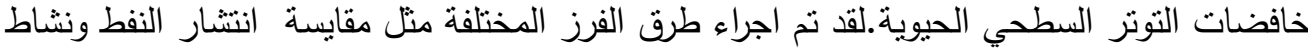

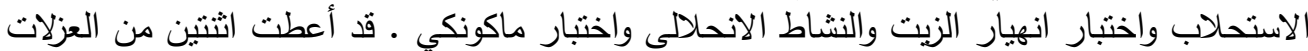

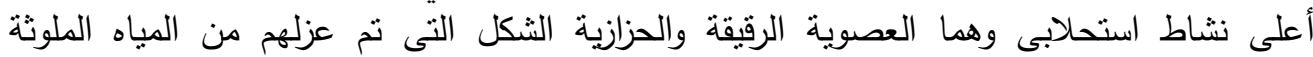

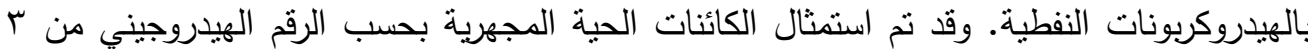

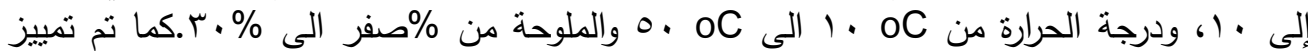

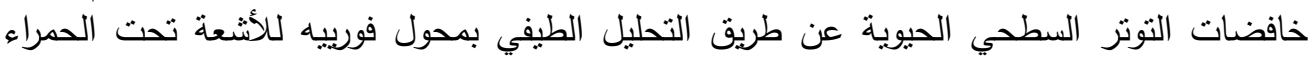

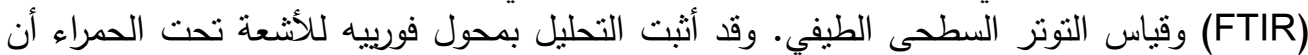

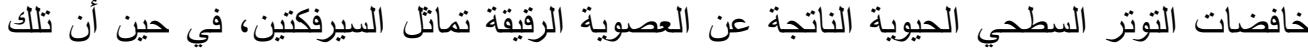

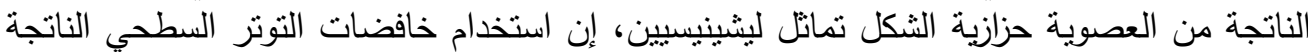


J. Environ. Sci.

Institute of Environmental Studies and Research - Ain Shams University

عن الميكروبات من شأنها أن تقلل بشكل كبير من عدم القابلية للأوبان في العياه وتزيد من معدل

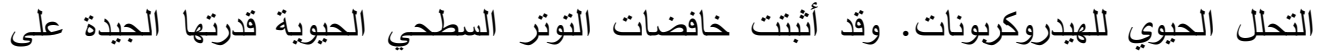

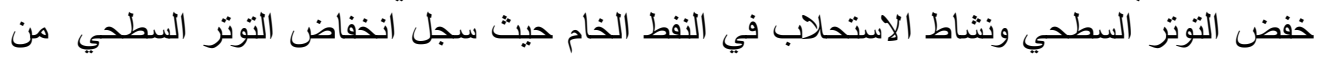

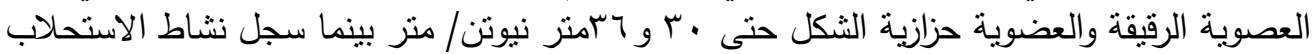

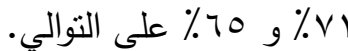

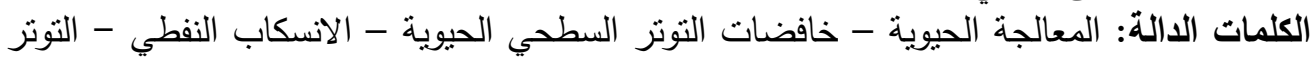
السطحي - النحليل الطيفي بمحول فورييه للأثنعة تحت الحمراء. 